\title{
Portland versus alkali-activated cement wall panels containing mine tailing as aggregate: one-story house thermal performance simulation in a Brazilian and Portuguese hot and humid climate
}

\author{
Miriam O. Baumbach ${ }^{1}$, Lucas T. S. Ramos ${ }^{1}$, Raquel P. Batista ${ }^{1}$, Raquel D. Oliveira ${ }^{1}$ and Paulo H. R. Borges ${ }^{1}$ \\ ${ }^{1}$ Department of Civil Eng., CEFET-MG, Av. Amazonas, 7675, Belo Horizonte, 30510-000, Brazil
}

\begin{abstract}
Alkali-activated materials (AAM) compared to Portland cement (PC) may significantly reduce the carbon dioxide emissions, as well as the consumption of nonrenewable natural resources in civil engineering applications. Further environmental advantages are possible if natural aggregates used for mortars and concretes are replaced with residues and wastes from industrial or mining activities. This paper compares the performance of PC with AAM as binders in cementitious wall panels for external cladding in hot and humid climate. Three different cementitious matrices are proposed, consisting of either $100 \%$ Portland cement (PC), $100 \%$ alkali-activated metakaolin (MK) or $80 / 20$ alkaliactivated Metakaolin/Blastfurnace slag (80/20 MK/BFS). Mortars were produced with the addition of tailing from iron-ore mining activities in the state of Minas Gerais, Brazil, at an aggregate to binder ratio of 1.0 for all matrices. The thermal property determined for the three mortars was Thermal Conductivity using a heat flow meter (HFM) apparatus according to ISO 8301 (1999); their apparent density was also measured. After that, onestory house building simulation was carried out using the Energy Plus Software. The main room annual operative temperature provided by different panels used as cladding was compared to the adaptive comfort range established on ASHRAE Standard 55/2013 for a Brazilian and Portuguese hot and humid climate. According to the Climate Zone Definitions of ANSI/ASHRAE Standard 169/2006, Belo Horizonte (Brazil) and Funchal (Portugal) were selected as a sample of $2 \mathrm{~A}$ zone that presents a hot and humid climate. Partial results of this research were presented in this paper. Results show that building simulations can effectively contribute to validate the selection of materials in the production of sustainable wall panels that provide suitable thermal conditions to the users in hot and humid climate.
\end{abstract}

\section{Introduction}

The diversity of concrete applications in construction is directly related to its wide range of variations in their physical characteristics according to their composition. Several studies have analysed the physical and mechanical behaviour of alkali-activated materials (AAM). The results point out that these materials are an alternative that not only presents a mechanical performance equivalent to the Portland cement (PC) but also advantages such as greater chemical and thermal resistance. In addition, the growing interest in AAM is directly related to their low environmental impact when compared to PC-based materials. The main environmental advantage of AAM over $\mathrm{PC}$ is the significantly lower $\mathrm{CO}_{2}$ emission rate in the former, up to $80 \%$ in some cases [1].
AAM are considered inorganic polymers obtained by the reaction between an aluminosilicate and an alkaline solution (activator solution). They can be produced by the activation of commercial materials such as metakaolin, fly ash, blast furnace slag and active silica [1-4]. The use of waste and tailings from mining processes as substitutes for natural aggregates has also been investigated around the world. Employment of mining by-products in AAM arises due to the significant increase in their generation in recent decades [5-7]. In Brazil, most of the wastes that derive from the extraction and processing of ores are located in dams, which can cause risk such as infiltration of solutions containing heavy metals and cyanides in the soil beside the control of the $\mathrm{pH}$ of these solutions. The geological-geotechnical control of these structures is of great importance, in

\footnotetext{
* Corresponding author: paulo.borges@,cefetmg.br
} 
order to maintain stability and avoid possible disruptions [8-9].

Certainly, one of the main obstacles to the AAM utilization in the construction industry is now standardization, rather than technological restrictions. Nevertheless, some important information on the thermal properties of geopolymers is still unavailable [1]. The description of building materials thermal properties could assist the design decisions. It is the case of the Brazilian thermal performance of residential buildings regulation NBR 15220/2005 and also on ISO $10456 / 2007$, both of which present different materials and their properties for designers $[10,11]$; AAM are not part of the list of materials available for designers. Yet, studies show that AAM may have lower specific heat and thermal conductivity values than $\mathrm{PC}$, which may enhance the material thermal performance in some climate conditions, since the thermal diffusivity is directly proportional to the thermal conductivity [12-14].

The present study aims at measure the thermal conductivity and apparent density of three different matrices containing mine tailing as aggregate (two AAM and a reference PC matrix). Furthermore, it intends to evaluate their thermal performance as wall panels through building simulation case study for a one-story house located in hot and humid climate in Brazil and Portugal.

\section{Materials and methods}

\subsection{Raw materials and formulation of the alkali activated mortars}

\subsubsection{Materials}

The AAM produced were obtained by the activation of metakaolin (MK) and blast furnace slag (BFS). The chemical composition and X-Ray diffraction pattern (XRD) of those aluminosilicates and aggregate (mine tailing) are presented in Table 1 and Figure 1, respectively.

Table 1 - Chemical composition of the solid precursors and mine tailing

\begin{tabular}{|l|r|r|r|}
\hline & $\begin{array}{c}\text { MK } \\
(\%)\end{array}$ & $\begin{array}{c}\text { BFS } \\
(\%)\end{array}$ & \multicolumn{1}{c|}{$\begin{array}{c}\text { Tailing } \\
(\mathbf{\%})\end{array}$} \\
\hline $\mathrm{SiO}_{2}$ & 43.55 & 34.95 & 82.78 \\
\hline $\mathrm{Al}_{2} \mathrm{O}_{3}$ & 37.00 & 12.63 & 2.35 \\
\hline $\mathrm{K}_{2} \mathrm{O}$ & - & 0.93 & 0.1 \\
\hline $\mathrm{CaO}$ & 0.05 & 32.74 & - \\
\hline $\mathrm{MgO}$ & 0.05 & 5.38 & - \\
\hline $\mathrm{Fe}_{2} \mathrm{O}_{3}$ & 2.00 & 2.30 & 13.86 \\
\hline Specific gravity & 2.59 & 2.86 & \\
\hline Mean particle size $(\mu \mathrm{m})$ & 2.12 & 8.75 & \\
\hline
\end{tabular}

MK is composed mainly of $\mathrm{SiO}_{2}$ and $\mathrm{Al}_{2} \mathrm{O}_{3}$, and it is mostly amorphous; XRD peaks for quartz, illite and muscovite indicates impurities in the kaolin source, whereas the peaks for kaolinite show some incomplete dehydroxylation of kaolin during the calcination process.
BFS is rich in calcium $(\mathrm{CaO}=32.74 \%)$, which will change the composition of the alkali-activated matrix; XRD peaks for gehlenite and akermanite are typical of slags from pig iron. The iron-ore tailing employed as aggregate results from the mining activities in the state of Minas Gerais, Brazil; it is composed of mainly quartz and hematite, with some XRDs peaks for kaolinite probably resulted from contamination. Figure 2 shows the particle size distribution of this aggregate, which has specific gravity of 2.95 and fineness modulus of 0.14 .

Sodium hydroxide $(50 \%$ vol.) and sodium silicate solutions $\left(\mathrm{Na}_{2} \mathrm{O}=15.00 \%, \mathrm{SiO}_{2}=31.79 \%\right.$ and $\mathrm{H}_{2} \mathrm{O}=$ $53.21 \%$, in \% wt.) were used as the alkaline activators. For the production of the reference matrix a commercially available rapid-hardening Portland cement (type CPV-ARI, Brazilian standard) was used.
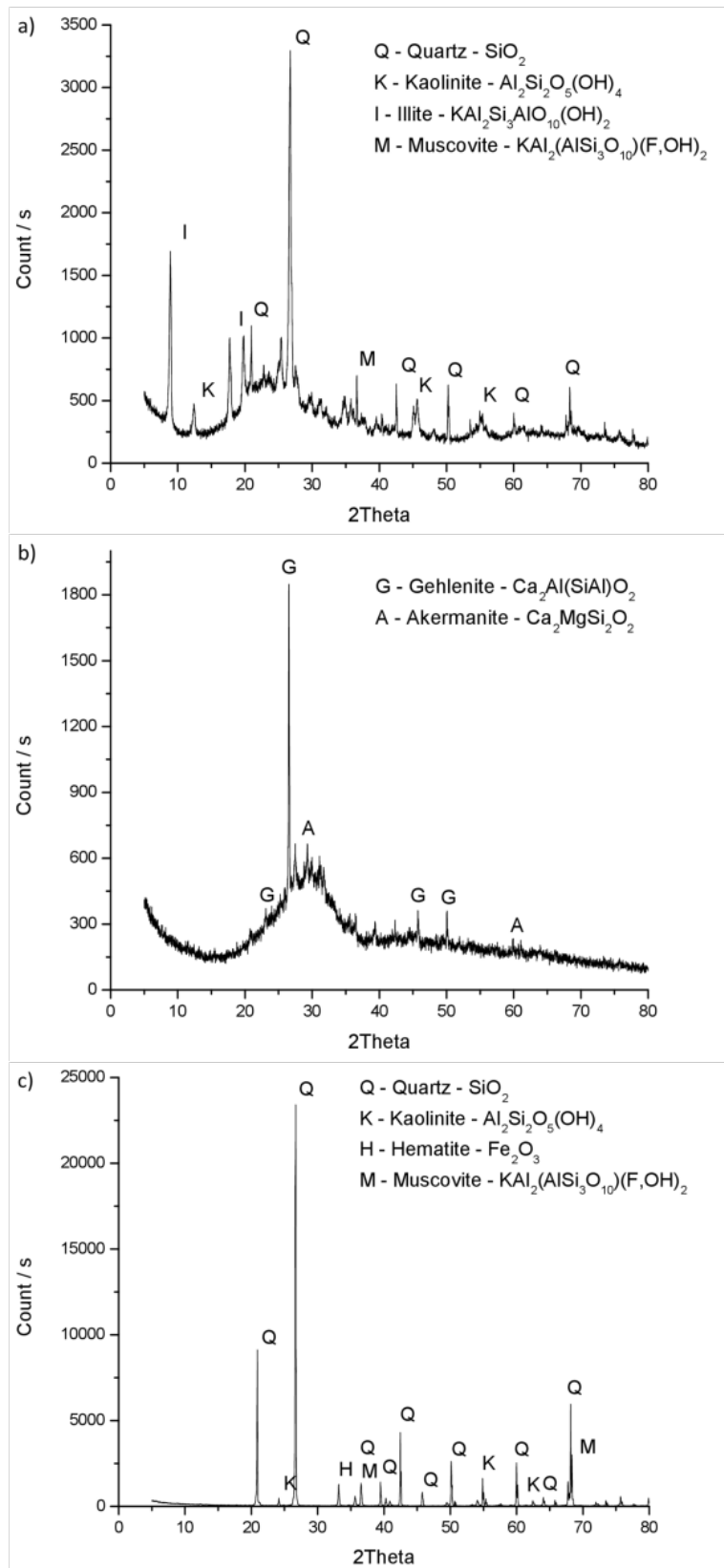

Figure 1. XRD pattern for (a) MK, (b) BFS and (c) mine tailing. 


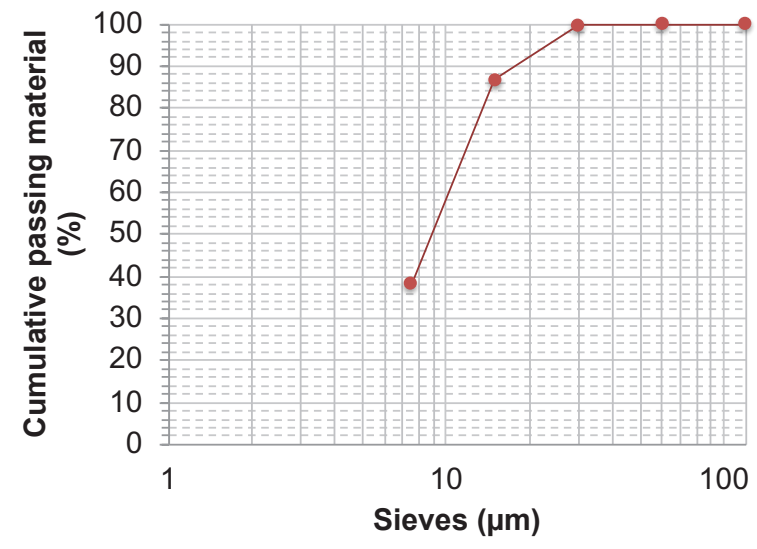

Figure 2. Particle size distribution of the iron-ore mine tailing .

\subsubsection{Formulation design and specimens preparation}

The mix design parameters used for the preparation of the AAM are shown in Table 2. A $\left[\mathrm{SiO}_{2}\right] /\left[\mathrm{Al}_{2} \mathrm{O}_{3}\right]$ molar ratio of 3.0 was adopted for both AAM matrices. The alkaline solutions consisted of a mixture of sodium silicate $\left(\mathrm{Na}_{2} \mathrm{SiO}_{3}\right)$ and sodium hydroxide $(\mathrm{NaOH})$. The solution to binder ratio and $\mathrm{Na}_{2} \mathrm{SiO}_{3}$ to $\mathrm{NaOH}$ ratio (wt.) varied in each mix, but the $\left[\mathrm{H}_{2} \mathrm{O}\right] /\left[\mathrm{Na}_{2} \mathrm{O}\right]$ molar ratio was kept constant and equals to 13.6. All mortars were prepared with an aggregate to binder ratio of 1.0. The alkali-activated mortars were named as follows: PC for the reference PC mortar; $100 \mathrm{MK}$ for the $100 \% \mathrm{MK}$ AAM; $80 / 20 \mathrm{MK} / \mathrm{BFS}$ for $80 \% \mathrm{MK} / 20 \%$ BFS AAM mortar (Table 2). For AAM mortars the alkaline solutions were mixed together on the day of casting to prepare the liquid component of the mixture. When BFS was employed, the two binders (MK+BFS) were firstly dry-mixed. The alkaline activator was then added to the dry mix and the matrix was mixed for 3 minutes. Finally, the aggregate was gradually added while mixing until the mortar presented a homogeneous appearance. A similar procedure was employed in the manufacturing of the reference mortar (PC). For this last one, a commercial superplasticizer, previously mixed in water, was employed at a dosage of $2 \%$ by mass of cement, so that the overall water to cement ratio was reduced $(0.38)$.

The mortars were cast in $300 \times 300 \times 20 \mathrm{~mm}$ moulds for the determination of thermal conductivity and 100x50 mm cylindrical moulds for compressive and determination of the apparent density. The specimens were exposed to ambient curing conditions until they reached the testing age (28 days).

Table 2. Formulation parameters

\begin{tabular}{|c|c|c|c|c|c|c|}
\hline Formulation & $\begin{array}{c}\mathrm{MK} \\
(\%)\end{array}$ & $\begin{array}{c}\mathrm{BFS} \\
(\%)\end{array}$ & $\begin{array}{c}\mathrm{OPC} \\
(\%)\end{array}$ & $\begin{array}{c}\text { Solution } \\
/ \text { Binder } \\
\text { Ratio }\end{array}$ & $\begin{array}{c}{\left[\mathrm{SiO}_{2}\right] /} \\
{\left[\mathrm{Al}_{2} \mathrm{O}_{3}\right]}\end{array}$ & $\begin{array}{c}{\left[\mathrm{SiO}_{2}\right] /} \\
{\left[\mathrm{Na}_{2} \mathrm{O}\right]} \\
\text { in the } \\
\text { activator }\end{array}$ \\
\hline $\mathrm{PC}$ & 0 & 0 & 100 & 0.38 & - & - \\
\hline $100 \mathrm{MK}$ & 100 & 0 & 0 & 1.09 & 3.0 & 1.29 \\
\hline $\begin{array}{c}80 / 20 \\
\text { MK/BFS }\end{array}$ & 80 & 20 & 0 & 0.91 & 3.0 & 1.01 \\
\hline
\end{tabular}

\subsection{Determination of physical and thermal properties of the mortars}

\subsubsection{Specific heat and Thermal conductivity}

The ASTM 351-b details a specific calorimeter to define the specific heat of the materials. However, for a preliminary study, it was adopted the specific heat found in the literature proper to AAM and PC concrete (Table $3)$.

Table 3. Specific heat values. Adapted from Snell et. al and ISO $10456[13,11]$.

\begin{tabular}{|c|c|c|}
\hline Material & Temperature $\left({ }^{\mathbf{o}} \mathbf{C}\right)$ & Specific Heat $(\mathbf{J} / \mathbf{k g} \cdot \mathbf{K})$ \\
\hline AAM & 20 & 730.1 \\
\hline $\begin{array}{c}\text { PC } \\
\text { concrete }\end{array}$ & 23 & 1000.0 \\
\hline
\end{tabular}

The thermal conductivity test was performed using the heat flow meter (HFM 436/1/3 from NETZSCH) apparatus according to ISO 8301 (1999) [15].

\subsubsection{Solar absorptance}

Solar absorptance data was obtained by calculation from the sample measurements made by ALTA II reflectance spectrometer, from Vernier Software \& Technology. This equipment performs measurements corresponding to radiation in eleven different wavelengths between 470 and $940 \mathrm{~nm}$, seven in the visible region and four in the near-infrared region. The analyses were performed as described by Sangoi et al. [16].

\subsubsection{Apparent dry density}

Apparent dry density was measured by dividing the mass of oved dried samples by their volume (cylindrical samples).

\subsection{Simulation}

The thermal comfort conditions of a single-family house $\left(24 \mathrm{~m}^{2}\right)$ were tested for a hot and humid climate defined as 2A zone by ANSI/ASHRAE Standard 169/2006 [17]. Belo Horizonte and Funchal were chosen as representative cities of Brazil and Portugal, respectively. A 3D model (Figure 3a) was created using SketchUp software associated to Euclid extension that create and modify the geometry inputs for building energy models. The building envelope was designed according to the $2 \mathrm{~A}$ climate zone requirements established in ASHRAE Standard 90.1/2013 [18]. Figure 3 b shows that the roof is composed of thermo-acoustic metal tile $(0.43 \mathrm{~mm})$ filled in with polyurethane $(30 \mathrm{~mm})$, aluminium foil fiberglass as under-coverage $(63 \mathrm{~mm})$, an air space greater than $5 \mathrm{~cm}$, a concrete slab $(10 \mathrm{~cm})$, another air space greater than $5 \mathrm{~cm}$ and a glass-wool ceiling $(35 \mathrm{~mm})$ which achieve $0.217 \mathrm{~W} /\left(\mathrm{m}^{2} \mathrm{~K}\right)$ of thermal transmittance $(\mathrm{U})$ and 21 hours of thermal lag $(\varphi)$. The building walls may be 
composed of three options (PC, 100MK and 80/20 MK/BFS panels) produced with $2 \mathrm{~cm}$ of thickness for inner and outer panels filled up with $8 \mathrm{~cm}$ of EPS (expanded polystyrene) (Table 4). The building floor (Figure $3 \mathrm{c}, \mathrm{U}=0.598 \mathrm{~W}\left(\mathrm{~m}^{2} . \mathrm{K}\right)$ ) is composed of concrete slab $(5 \mathrm{~cm})$, glass-wool $(63 \mathrm{~mm})$ and laminate wood flooring $(7 \mathrm{~mm})$. The glass material properties adopted for the windows present $\mathrm{U}=3.629 \mathrm{~W}\left(\mathrm{~m}^{2} . \mathrm{K}\right)$, solar factor $\mathrm{SF}=0.517,6 \mathrm{~mm}$ of thickness. The main room window present $1.5 \times 1.2 \mathrm{~m}$ of width and height faced to the north direction for Belo Horizonte and the double width and the same height faced to the south direction for Funchal to enhance the internal gains on winter. Besides, a $50 \mathrm{~cm}$ deep overhang was considered for Belo Horizonte in order to reduce heat gains. For the house units in both cities, an outdoor window blind was considered for the main room which is used when the outdoor temperatures exceeds $26^{\circ} \mathrm{C}$. The case-study house made up of three different wall panel options was evaluated through a computer simulation by Energy Plus considering their indoor temperature according the weather data file of the city in which is located. The simulation output, i.e. the annual operative temperature of the main room, was compared to the adaptive comfort range according to the ASHRAE Standard 55/2013 [19] reference, for $80 \%$ occupant acceptability. The main room operable window was assumed to be opened if the operative temperature is greater than the comfort temperature (central line) calculated from the ASHRAE Standard 55 adaptive comfort model and venting availability schedule allows venting. In addition, the house was considered unoccupied (without lighting power, equipment, people, etc.).

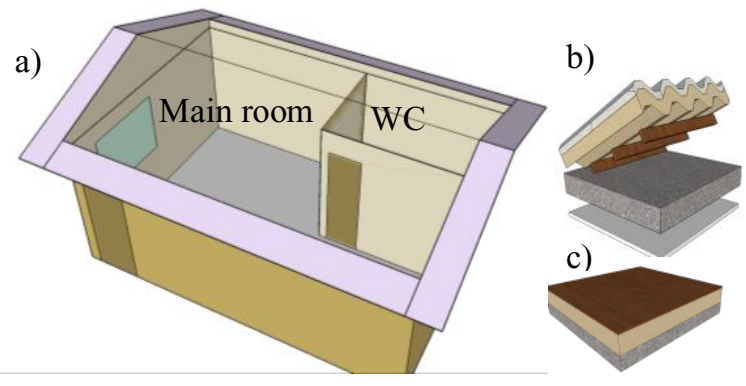

Fig. 3. Single-family house unit: (a) main zone; (b) roof recovering and floor.

Table 4. Design of building envelope and its thermal transmittance and thermal capacity values.

\begin{tabular}{|c|c|c|c|c|c|c|}
\hline \multirow{2}{*}{ Plate } & \multirow{2}{*}{ Walls } & \multirow{2}{*}{ Composition } & \multicolumn{2}{|c|}{ Thermal transmittance $\left[\mathrm{W} /\left(\mathrm{m}^{2} \mathrm{~K}\right)\right]$} & \multirow{2}{*}{\begin{tabular}{|c}
$\begin{array}{c}\text { Thermal capacity } \\
{\left[\mathrm{kJ} / \mathrm{m}^{2} \mathrm{~K}\right]}\end{array}$ \\
Observed
\end{tabular}} & \multirow{2}{*}{\begin{tabular}{|c|} 
Thermal lag [h] \\
Observed
\end{tabular}} \\
\hline & & & $\begin{array}{c}\text { Maximum } \\
\text { (ASHRAE 90.1) }\end{array}$ & Observed & & \\
\hline Cement & & $\begin{array}{l}\text { 1) Cement phate (2cm) } \\
\text { 2) EPS (8cm) } \\
\text { 3) Cement phate (2cm) }\end{array}$ & 0.479 & 0.427 & 92 & 6.7 \\
\hline $100 \% \mathrm{MK}$ & & $\begin{array}{l}\text { 1) } 100 \% \text { MK plate }(2 \mathrm{~cm}) \\
\text { 2) EPS }(8 \mathrm{~cm}) \\
\text { 3) } 100 \% \text { MK plate (2cm) }\end{array}$ & 0.479 & 0.422 & 56 & 5.3 \\
\hline $80 \% \mathrm{MK} / 20 \% \mathrm{BFS}$ & & 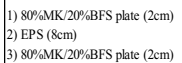 & 0.479 & 0.418 & 57 & 5.3 \\
\hline
\end{tabular}

\section{Results}

The results of absorptance, apparent density and thermal conductivity measured for the 3 different wall panels are shown in Table 5. The 100 MK mortar had an absorptance of 0.694 , apparent density of $1.77 \mathrm{~g} / \mathrm{cm}^{3}$ and $0.186 \mathrm{~W} /(\mathrm{m} . \mathrm{K})$ thermal conductivity. In the $80 / 20$ MK/BFS sample the absorptance was 0.910 , the density $1.83 \mathrm{~g} / \mathrm{cm}^{3}$ and the thermal conductivity $0.188 \mathrm{~W} /(\mathrm{m} . \mathrm{K})$. For the reference panel (PC), the absorptance, apparent density and thermal conductivity were, $0.816,2.20 \mathrm{~g} / \mathrm{cm}^{3}$ and $0.100 \times \mathrm{W} /(\mathrm{m} . \mathrm{K})$, respectively. These results agree with those found in the literature, in which thermal conductivity is lower in AAM then in PC [12-14].

Table 5. Results of absorptance, apparent density and thermal conductivity for the 3 samples analysed.

\begin{tabular}{|c|c|c|c|}
\hline Sample & Absorptance & $\begin{array}{c}\text { Apparent } \\
\text { density } \\
\left(\mathbf{g} / \mathbf{c m}^{\mathbf{3}} \mathbf{)}\right.\end{array}$ & $\begin{array}{c}\text { Thermal } \\
\text { Conductivity } \\
\mathbf{W} /(\mathbf{m} . \mathbf{K})\end{array}$ \\
\hline $\mathrm{PC}$ & 0.816 & 2.20 & 0.23 \\
\hline $100 \mathrm{MK}$ & 0.694 & 1.77 & 0.20 \\
\hline $\begin{array}{c}80 / 20 \\
\mathrm{MK} / \mathrm{BFS}\end{array}$ & 0.910 & 1.83 & 0.18 \\
\hline
\end{tabular}

Through computer simulation it could be noticed that the $100 \mathrm{MK}$ wall panel had the best performance for Belo Horizonte, presenting $86 \%$ thermal comfort hours, against $82 \%$ presented by the PC panel and $72 \%$ by the $80 / 20 \%$ MK/BFS. However, for Funchal city, the PC wall panel provided $77 \%$ thermal comfort hours, against $74 \%$ for $100 \mathrm{MK}$ and $72 \%$ for $80 / 20 \mathrm{MK} / \mathrm{BFS}$ wall panels (Figure 4).

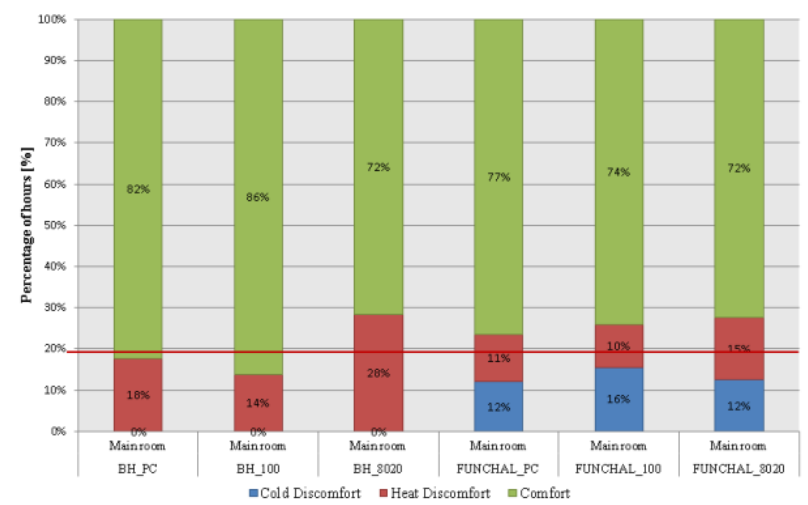

Fig. 4. Percentage (in hours) of annual thermal comfort for PC, $100 \mathrm{MK}$ and $80 / 20 \mathrm{MK} / \mathrm{BFS}$ wall panels in Belo Horizonte and Funchal cities.

The comparison between thermal comfort range according to the ASHRAE Standard 55/2013 and operative temperature of the main room simulated for 3 options of wall panels shows that $100 \mathrm{MK}$ provided lowest indoor temperatures, throughout the year and 80/20 MK/BFS the highest for Belo Horizonte (Figure 5). The PC provided similar results compared to 100 MK. However, the minimum temperature value is slightly higher for the PC panel, which demonstrated a greater potential for thermal damping. The heat discomfort, sometimes, was quite far above the upper comfort limit of ASHRAE Standard 55, which indicates 
that some changes could be performed on the building envelope in order to reduce this number of hours' discomfort. Perhaps the isolated sealing, the thermal lag greater than $5 \mathrm{~h}$ for all options of wall panels, associated to the cement compositions that presents a thermal inertia potential (thermal capacity greater than $56 \mathrm{~kJ} / \mathrm{m}^{2} . \mathrm{K}$ ) combined with high solar absorptance (greater than 0.7) hindered heat loss when external temperatures were high. The employment of a panel lighter in colour, i.e. with a lower value of solar absorptance, could contribute to reduce the heat hours' discomfort. On the other hand, this special feature seems to contribute to maintain the indoor temperatures when the outdoor temperatures were low. Therefore, the cold discomfort did not take place.

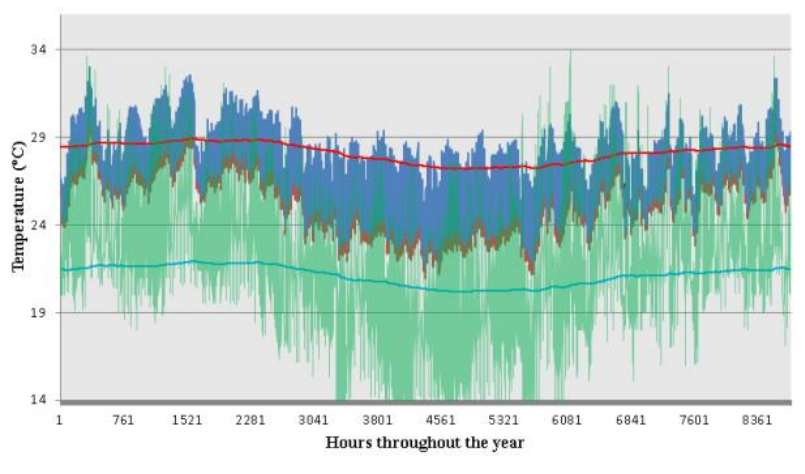

Fig. 5. Comparison between thermal comfort range of ASHRAE Standard 55 and operative temperature of PC, 100 MK and 80/20 MK/BFS wall panels, which change according to Dry Bulb Temperature (DBT) for Belo Horizonte.

Similar comparison was performed for Funchal. Figure 6 indicates different performance of the wall panels through the year in comparison between Belo Horizonte. It is possible to note that the maximum temperatures significantly exceed the upper comfort limit, especially in summer and in the beginning of fall. The minimum temperatures were far below from the lower comfort limit, during the fall and winter. The discomfort hours at low temperatures (cold climate) were greater than at high temperature (heat), except for the $80 / 20 \mathrm{MK}$ panel. However, the maximum operative temperatures were more extreme for hot conditions, although the maximum DBT did not surpass the $28.8^{\circ} \mathrm{C}$ while the operative surpassed the $32.0^{\circ} \mathrm{C}$, in some cases. The thermal inertia potential of the cement wall panel (herewith an insulate sealing) associated with a high thermal absorptance makes the building system accumulate a significant amount of heat during the hot seasons. For this city, some changes could also be made in order to enhance the comfort hours during the summer. In this case, a lighter colour on the external panel could contribute to reduce the heat hours' discomfort but, on the other hand, will increase the cold hour's discomfort. To reduce the heat discomfort hours without increase significantly the cold discomfort through the year, the thermal capacity of the wall panels should be increased.

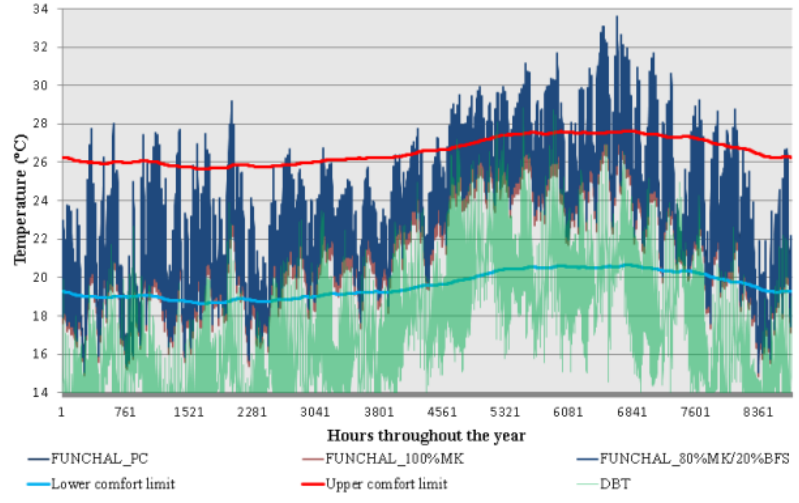

Fig. 6. Comparison between thermal comfort range of ASHRAE Standard 55 and operative temperature of PC, $100 \% \mathrm{MK}$ and $80 / 20 \mathrm{MK} / \mathrm{BFS}$ plates, which change according to DBT for Funchal.

\section{Conclusions}

The thermal conductivity, apparent density and solar absorptance of three different mortars, consisting of either 100\% Portland cement (PC), 100\% alkaliactivated metakaolin (MK) or $80 / 20$ alkali-activated Metakaolin/Blastfurnace slag (80/20 MK/BFS) were performed. The Energy Plus building simulation of a one-story house unit enabled to evaluate the thermal behaviour of those materials as cladding for a hot and humid climate. Belo Horizonte and Funchal were chosen as representative cities of Brazil and Portugal, respectively, considering the $2 \mathrm{~A}$ zone addressed on ANSI/ASHRAE Standard 169/2006. The results showed that those materials, in compliance with ASHRAE Standard 90.1/2013, could be adopted as a wall panel although a schedule of building use and occupation was not considered. Relevant comfort hours throughout the year could be noticed in comparison between the adaptive comfort ranges established by ASHRAE Standard 55/2013 (greater than $72 \%$ for both cities). Further studies could test different arrangements of the wall panels composition and colour made up of those materials. However, this research can contribute to foster new studies and to highlight thermal data of an alternative and more sustainable building material option in comparison to Portland cement panels.

\section{Acknowledgements}

The authors would like to thank CNPq, CAPES, FAPEMIG and CEFET-MG for supporting this research, CDTN for the donation of waste, and Ares architecture for lending the spectrophotometer.

\section{References}

1. P. Duxson, J. L. Provis, G. C. Lukey, J. S. J. van Deventer. The role of inorganic polymer technology in the development of 'green concrete'. Cem. Concr. Res. 37 (2007) 1590-1597 
2. J. Temuujin, W. Rickard, M. Lee, A. Van Riessen, Preparation and thermal properties of fire resistant metakaolin-based geopolymer-type coatings, J. Non. Cryst. Solids. 357 (2011) 13991404. doi:10.1016/j.jnoncrysol.2010.09.063.

3. F. Škvára, T. Jílek, L. Kopecký, Geopolymer materials based on fly ash, Ceram. - Silikaty. 49 (2005) 195-204.

4. A. Palomo, M.W. Grutzeck, M.T. Blanco, Alkaliactivated fly ashes: A cement for the future, Cem. Concr. Res. 29 (1999) 1323-1329. doi:10.1016/S0008-8846(98)00243-9.

5. G. Kastiukas, X. Zhou, J. Castro-Gomes, Towards Preparation Conditions For The Synthesis Of Alkali-Activated Binders Using Tungsten Mining Waste, ASCE's J. Mater. Civ. Eng. (2017) 1-35. doi:10.1061/(ASCE)MT.1943-5533.0002029.

6. N. Sedira, J. Castro-Gomes, G. Kastiukas, X. Zhou, A. Vargas, A review on mineral wasten for alkali-activated binders due to their chemical characteristics, Min. Sci. 24 (2017) 29-58. doi:10.5277/msc172402.

7. J.L. Provis, V. Deventer, J. S.J., Geopolymers. Structures, Processing, Properties and Industrial Applications, 2009. doi:10.1533/9781845696382.

8. X. Jiao, Y. Zhang, T. Chen, Thermal stability of a silica-rich vanadium tailing based geopolymer, Constr. Build. Mater. 38 (2013) 43-47. doi:10.1016/j.conbuildmat.2012.06.076.

9. IBRAM, Gestão e Manejo de Rejeitos da Mineração, (2016).

10. ABNT. NBR 15.220-5: Desempenho térmico de edificações. Parte 5: Medição da resistência térmica e da condutividade térmica pelo método fluximétrico. Rio de Janeiro, (2005).

11. ISO. ISO 10456-2007. Building materials and products - Hygrothermal properties - Tabulated design values and procedures for determining declared and design thermal values. ISO, Switzerland; (2005).

12. F. Colangelo, G. De Luca, C. Ferone, A. Mauro, Experimental and Numerical Analysis of Thermal and Hygrometric Characteristics of Building Structures Employing Recycled Plastic Aggregates and Geopolymer Concrete. Energies, 6, (2013), 6077-6101; doi:10.3390/en6116077.

13. C. Snell, B. Tempest, A. M. ASCE, T. Gentry, Comparison of the Thermal Characteristics of Portland Cement and Geopolymer Cement Concrete Mixes. J. Archit. Eng. 23, (2017). doi:10.1061/(ASCE)AE.1943-5568.0000240.

14. L. A. C. Bezerra. Análise do desempenho térmico de sistema construtivo de concreto com EPS como agregado graúdo. Dissertação de mestrado. UFRN. (2003).

15. ISO. ISO 8301-1999. Thermal insulation Determination of steady-state thermal resistance and related properties - Heat flow meter apparatus. ISO, Switzerland; (1999).

16. J. M. Sangoi, G. Ramos, R. Lamberts, Análise das medições de absortância através do Espectrômetro alta II. In: Anais XIII Encontro Nacional de Tecnologia do Ambiente Construído. Canela, RS. 2010.

17. ASHRAE. ANSI/ASHRAE Standard 169-2006. Climatic Data for Building Design Standards. ASHRAE, Atlanta, (2006).

18. ASHRAE. ANSI/ASHRAE Standard 90.1-2013: Energy Standard for Building Except Low-Rise Residential Buildings. ASHRAE, Atlanta, (2013).

19. ASHRAE. ANSI/ASHRAE Standard 55-2010. Thermal environmental conditions for human occupancy. ASHRAE, Atlanta, (2010). 